\title{
ОСОБЕННОСТИ РАЗВИТИЯ ТВОРЧЕСКОГО ПОТЕНЦИАЛА ПОДРОСТКОВ СРЕДСТВАМИ ТЕАТРАЛЬНОЙ ПЕДАГОГИКИ
}

\section{FEATURES OF THE DEVELOPMENT OF THE CREATIVE POTENTIAL OF ADOLESCENTS BY MEANS OF THEATER PEDAGOGY}

\section{Gurenko}

Summary: The development of the creative personality of conditions for his self-determination and self-realization is one of the tasks set by the Law of the Russian Federation "On Education". Theater pedagogy is an effective means of activating the creative potential of a child, developing his general culture and personality as a whole potential of adolescents by means of theater pedagogy. For this purpose, the author considered the issues of the peculiarities of the development of creative abilities of adolescents. The definition of the concept of "theater pedagogy" is compiled. For the successful development of the creative potential of adolescents, a certain environment must be organized. The possibilities of children's musical theater, as a means of theater pedagogy, in the creative development of adolescent children are revealed. In conclusion, the author came to the conclusion that every child needs to create conditions in which he could creatively express himself and develop his abilities. The definition of the concept of "theater pedagogy" is compiled. For the successful development of the creative potential of adolescents, a certain environment must be organized. The possibilities of children's musical theater, as a means of theater pedagogy, in the creative development of adolescent children are revealed. In conclusion, the author came to the conclusion that every child needs to create conditions in which he could creatively express himself and develop his abilities. We need an atmosphere of joy that evokes positive emotions; an activity in which positive qualities of the individual are formed. Such conditions can be created within the framework of children's musical theater, where teenagers with different levels of musical development can express themselves both in music and in other activities.

Keywords: creative potential, creativity of teenagers, adolescence, theater pedagogy, creative environment, creative abilities, children's theater, means of theater pedagogy.
Гуренко Максим Владимирович

аспирант, ФГБОУ ВО «Тамбовский государственный университет имени Г.Р. Державина», г. Тамбов maxsimum14@mail.ru

Аннотация: Главной задачей, которая отражена в законодательстве нашей страны, в частности в ФЗ РФ «0б образовании», можно считать работу по формированию творческих начал у подростков и созданию условий для того, чтоб ребенок мог самоопределиться и самореализоваться. Поэтому театральную педагогику можно рассматривать в качестве мощного средства, дающего возможность подростку раскрыть и активизировать собственный творческий потенциал, развивать свою общую культуру и личность в целом. Таким образом, статья посвящена особенностям развития творческих способностей у подростков. Цель работы - изучить особенности творческого потенциала подростков средствами театральной педагогики. Для этого автором были рассмотрены вопросы особенности развития творческих способностей подростков. Составлено определение понятия «театральной педагогики». Для успешного развития творческого потенциала подростков должна быть организована определенная среда. Выявлены возможности детского музыкального театра, как средства театральной педагогики, в творческом развитии детей подросткового возраста. В заключении автор пришел к выводу 0 том, что для самовыражения ребенка необходимо создание определенных условий, что позволит реализовать собственные способности. Ребенок должен ощущать атмосферу радости, что дает ему массу положительных эмоций. Помимо этого, ребенок должен быть вовлечен в деятельность, благодаря которой могут быть сформированы положительные качества личности. Ряд вышеперечисленных условий может обеспечить участие в музыкальном театре, где дети разного возраста, имея различный уровень музыкального развития, имеют множество возможностей проявления себя как в деятельности музыкального характера, так и в деятельности иного рода.

Ключевые слова: творческий потенциал, творчество подростков, подростковый возраст, театральная педагогика, творческая среда, творческие способности, детский театр, средства театральной педагогики.

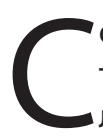

овременное общество характеризуется более твердыми и зачастую жесткими требованиями к личности. Считается, что человек интересен тогда, когда он самостоятелен, креативен, индивидуален, харизматичен. Проще найти собственное место в обществе, если уметь нестандартно мыслить и также находить нестандартный выход из любой ситуации. Скорее всего, это и является предпосылкой формирования некоего социального заказа к системе образования и воспитания, что даст возможность формирования «на выходе» личности с указанными свойствами [3].

С другой стороны, в начале нынешнего века был осуществлен переход к обновленной концепции системы образования, которая ориентирована именно на личность, индивидуальность, самобытность и уникальность каждого ребенка.

Вышеназванные тенденции находятся В противоречии друг к другу. Тем не менее, их можно считать и 
опорой друг для друга, так как на первое место ставится именно личность каждого ребенка, ведется работа по выявлению неповторимости природных задатков каждого ребенка, его творческих способностей.

Уже не первый год общество решает проблему, являющуюся актуальной, по сохранению интеллектуального потенциала нации. Не менее важным является развитие и создание определенных условий для талантливых детей в нашей стране, так как именно талантливые личности - важная производственная и творческая сила прогресса [1].

В наших учебных заведениях в большинстве своем обучаются дети со средними данными и особенностями психики, что вовсе не значит, что и подход к ним должен быть применен усредненный.

Искать и раскрывать творческий потенциал подрастающего поколения - важная задача нашего общества. И именно период подросткового возрасте - наиболее продуктивное время для развития творческого потенциала личности: многие, будучи подростками, пробовали себя в написании стихов, в рисовании картин, овладении музыкальными инструментами, «прыгая» из стиля в стиль, от одного образа к дуговую. Подростковый - возраст кризисный. И именно благодаря своей «кризисности» в этом возрасте у ребенка открывается ряд новых граней, ребенок переходит на качественно новый уровень, взрослеет как личность, ищет в себе задатки именно творческой личности [15].

Творческие личности, творчество - это то, что движет нашим обществом, это является движущей силой всего человечества. Работа по формированию таких личностей - насущная задача специалистов различных сфер науки, культуры, психологии, педагогики и т.д. При этом продуктивность в решении задач по формированию, развитию и становлению творческой личности зависит еще от школы, от того, насколько грамотно организована воспитательная и образовательная работа с подростками.

Творческий потенциал является своеобразным триггером к механизму саморазвития и формирования творческого начала в каждом человеке [2]. Но именно момент самостоятельности зачастую наделен противоречиями между необходимостью передать подрастающему поколению с каждым днем увеличивающийся запас социально-значимых знаний и соответствия этого запаса индивидуальным возможностям и потенциалу каждого человека в отдельности.

Более безопасным и надежным средством для саморазвития творческой личности можно считать театральную деятельность, которая является инструментом теа- тральной педагогики.

Театральная педагогика далеко не нова. Ее использовали в образовательной деятельности еще в Античные времена [14]. Ведь школу и театр роднит очень многое: и в школе, и в театре педагоги создают некую модель мира, своеобразные микро-миры, где обучающиеся взаимодействуют друг с другом, работают, сотрудничают, ссорятся, идут на компромисс, достигают целей и результатов.

Подростки имеют крайне малый жизненный опыт. Круг их общения, их микро-мир - их сверстники со сходим жизненным опытом. А цель, как школы, так и театра, - сформировать социально-адаптированного гражданина, всестороннюю, гармоничную личность. Это становится благодаря использованию средств, методов и приемов театральной педагогики [3].

Эффективность средств театральной педагогики в воспитании подрастающего поколения неоднократно подчеркивали зарубежные, отечественные педагоги, выдающие деятели советского периода - Макаренко, Луначарский, Выготский. Интерес к театральной педагогике возрастает с каждым днем. В качестве примера стоит хотя бы привести проведение ежегодных муниципальных, областных, международных фестивалей школьных театров.

Суть театральной педагогики - вовлечь ребенка в речевое общение более активным образом, сделав разнообразной гамму эмоций, переживаний. Театральная педагогика вводит ребенка в мир, где тот может раскрепостить интеллект [13].

При постановке спектакля происходит не только игровое действие и развлечение. Постановка спектакля - это метод, позволяющий стимулировать творческую активность ребенка. Благодаря участию в театральной постановке у подростков увеличивается уровень речевого общения. Подросткам более наглядно открывается работа актера, инструментарий его деятельности, его природ: движения, тело, речь, жесты, мимика и т.д. [4] Это способствует тому, что подросток начинает подражать актеру, стараться играть роль, которую ему доверили, с большей правдоподобностью. Это стимулирует подростка для дальнейшего развития, для совершенствования его действий, речи и т.д.

Введение театральной деятельности в жизнь подростка - не только средство для развлечения, а больше в качестве некоего стимула проявить себя с другой стороны, проявить собственные творческие задатки. При этом педагог в данном случае ориентирован не столько на подростка как ученика, а как на личность. 
Благодаря театральной деятельности формируется нравственность в поведении, дети учатся принимать решения согласно нравственным нормам и канонам [12]. Благодаря реализации театральной деятельности многие подростки избавляются от болезненных переживаний, укрепляют собственное физическое и психическое здоровью, становятся более адаптированными к окружающему и, самое главное, могут раскрыть себя, свои таланты, показать свой внутренний мир.

Благодаря театральной педагогике акцентируется внимание подростка на обучении работе актера в театральной труппе, на то, чтоб творческий диапазон юного актера был обеспечен возможностью для расширения.

Практическая же работа в плане воспитания каждого преподавателя театрального искусства имеет под собой цель развивать наиболее важные качества в каждом воспитаннике. Такие качества - это развитие художественности и эстетизма [5]. И здесь крайне важным можно считать невозможность исключения какого-либо из указанных качества. Нельзя отдавать приоритет иному, так как в конечном счете это может обусловить крах театрального искусства.

Подростки с немалым интересом принимают участие не только в классических театральных постановках. Не меньший интерес вызывают и кукольные спектакли, участие в которых дает возможность испробовать себя не только в роли актера, но и режиссировать постановку, быть постановщиком и т.д. Это, в свою очередь, дает возможность педагогу увидеть те таланты, которые заложены в ребенке. Участие в кукольном театре способствует заинтересованности подростков в театре драматическом.

Театральное искусство отличается особой специфичностью: буквально с момента задумки постановки и до выпуска спектакля у педагога есть возможность непосредственного влияния на то, чтоб развивать, воспитывать и формировать личность подростка.

При выборе упражнений, заданий, этюдов, бесед или иных методов обучения, педагогу предоставляется возможность применения данных методов для развития личности подростка в целом: так, инструмент пианиста - рояль, скрипача - скрипка; актер же обладает такие инструментом, как он сам. И как будет произведена «настройка» данного «инструмента», так и будет развиваться личность. И такую «настройку» должен производить именно педагог. При «правильной настройке» учащийся может иметь прекрасное «звучание». Но может и наоборот, надолго закрыться для преподавателя [13].

Очень важны для педагога заинтересованность и любовь к подросткам. Немаловажной является то, на- сколько увлечен педагог собственной деятельностью, насколько он психолого- и педагогически зорок, наблюдателен, какой уровень его педагогического такта, воображения, как он умеет организовать собственные организаторские способности, насколько он справедлив, общителен, требователен, выдержан, профессионален и работоспособен.

Но для овладения такими качествами, которые были указаны ранее, необходимо изучение и освоение закономерностей и механизмов реализации педагогических процессов в театральной деятельности [6], что даст возможность разбивки каждой темы или раздела на ряд составных элементов; для осмысления каждой части во взаимосвязи с целым образом; для поиска основных проблем и способов решить возникающие проблемы корректно, оптимально и продуктивно. Но опорой в деятельности педагога должна выступать научная теория. Одна из характеристик театральной деятельности - коллективность. Взаимопонимание в педагогическом коллективе - залог достижения нужного результата [12].

Театр - наиболее зрелищный из многих видов искусства [7]. При этом театр является сосредоточением многих видов искусства, но характеризуется при этом собственной спецификой.

В деятельности музыкального театра соединены сценическое искусство, музыкальное и танцевальное. Здесь же присутствует вокальная и инструментальная музыка, поэзия, драматургия, хореография и изобразительное искусство.

Детский музыкальный театр является разновидностью театрального искусства, а синтез искусств - сочетание музыки и театра, - позволяет проявить себя с сценографии, костюмах, постановке, актерской игре, пении и ряда других. Все это объединяется для того, чтоб донести музыкальное содержание до зрителей, слушателей [11], детский музыкальный театр является действенным средством художественно-эстетического воспитания школьников.

Развивающие возможности театральной деятельности обусловлены ее синкретическим началом, интеграцией различных видов деятельности в процессе совместной деятельности по созданию коллективного художественного продукта [8]. Притягательность любительской театральной деятельности для детей и взрослых во многом обусловлена возможностью самореализации, раскрытия индивидуальности человека, выбора в рамках общей деятельности варианта, наиболее соответствующего личностным особенностям, потребностям, задачам развития каждого человека.

Театральная деятельность открывает простор для 
самовыражения, в том числе стимулирует к проявлению творческой активности, что благоприятно отражается на развитии творческих способностей, что способствует повышению внимания подростков, раскрытию его сообразительности, усиливают реакцию, заставляют быть организованными, уметь рассчитывать собственные действия, подчиняться конкретным образам, перевоплощаться в данные образы, жить жизнью персонажа и т.д.

Рассматривая вопросы творческого развития школьников, можно сказать, что «круг театрально-творческих проявлений и условий, созданных для этого, в школе может быть существенно расширен по сравнению с тем, как он существует и бытует сегодня».

Для работы с подростковым возрастом такую форму работы, как работу по обсуждению спектакля, можно назвать максимально эффективной [8]. При условии погружения подростка в мир спектакля, его образов, можно попробовать построить с ним диалог. И уже далее в самых разных условиях своей жизни подросток может возвращаться к нему не единожды, находя нужные аргументы в споре; опору для того, чтоб корректно строить собственное восприятие различных произведений искусства; находить материал, чтоб проводить самоанализ, анализ собственного творчества.

Благодаря участию в диалоге, обсуждении подростку становится под силу определять и гасить, нейтрализовать ряд негативных эмоций, избавиться от страха непонимания произведений театрального искусства. Обсуждение может быть помощью в построение внутреннего диалога с образами конкретного обсуждаемого спектакля и в целом сформировать позитивную установку на восприятие произведений театрального искусства [9].

Таким образом занимаясь театрализованной деятельностью, подростки делают собственную жизнь интересной и содержательной, наполненной яркими впечатлениями, интересными делами, радостью творчества.

Поэтому каждому ребенку необходимо создать условия, в которых он мог бы творчески самовыражаться и развивать свои способности. Нужна атмосфера радости, вызывающая положительные эмоции; деятельность, в которой формировались бы позитивные качества личности. Такие условия могут быть созданы, например, в рамках детского музыкального театра, где подростки с разным уровнем музыкального развития могут проявить себя как в музыкальной, так и в других видах деятельности.

\section{ЛИТЕРАТУРА}

1. Асмолов А.Г. Культурно-историческая психология и конструирование миров. -М.: Изд-во Института практической психологии; Воронеж: НПО «МО-ДЭК», 2019.

2. Батищев Г.С. Введение в диалектику творчества. - СПб.: Изд-во РХГИ, 2017. - 464 с.

3. Батищев Г.С. Диалектика и смысл творчества // Диалектика рефлексивной деятельности и научное познание. - Ростов н/Д.: Изд-во РГУ, 2018.

4. Батищев Г.С. Особенности культуры глубинного общения // Вопросы философии. - 2019. № 3

5. Бердяев И.А. Философия творчества, культуры и искусства: в 2 т. - М.: Искусство, 2019. —т. 1.

6. Библер В.С. Мышление как творчество: Введение в логику мысленного диалога. М.: Политиздат, 1975.

7. Вопросы режиссуры самодеятельного детского театра. Сборник научных работ ЛГИК им. Н.К. Крупской, Ленинград, 2018

8. Выготский Л.С. Психология искусства. - М.; Педагогика, 2017.

9. Выготский Л.С. Педагогическая психология / Под ред. В.В. Давыдова. М.: Педагогика, 2018.

10. Каршин И.А., Мышкин Е.И. «Опыт педагогики творчества». Научно = экспериментальные материалы КРУ. 2018.

11. Кнебель М.О. «Поэзия педагогики» Всерос.театр.0-во, М. 2018

12. Никитина А.Б. «Ребенок на сцене». Научно - методическое пособие «Я вхожу в мир искусств» 2018. № 12

13. Новицкая Л.П. «Уроки вдохновения» /ред. Ю.С. Калашников/ Всерос.театр.0-во, М. 2018.-383с.,ил.

14. Станиславский К.С. «Моя жизнь в искусстве» «Собрание сочинений в восьми томах. Том 1»: Искусство; Москва; 1954г.

15. Царенко Л., Соловьева Е. «Образование и театр»: Литературно-музыкальные композиции. -М.: ВЦХТ («Я вхожу в мир искусств»), 2018.- 160с.

(ㄷ Гуренко Максим Владимирович (maxsimum14@mail.ru).

Журнал «Современная наука: актуальные проблемы теории и практики» 